\title{
Hypericum perforatum
}

National Cancer Institute

\section{Source}

National Cancer Institute. Hypericum perforatum. NCI Thesaurus. Code C60535.

A member of the genus Hypericum. The plants are described as glabrous perennials, erect and usually woody at the base. The ovate to linear leaves are sessile, opposite, and well-supplied with translucent glandular dots. The regular flowers have five short, subequal, entire, imbricate, basally connate sepals, and five persistent-withering yellow petals. The ovary is superior, capsicular, and three-styled. Stamens are many, arranged in bundles of threes, and the flowers are profuse, arranged in branched cymes which bloom from June until September. It is native to Europe, West Asia, North Africa, Madeira and the Azores, and is naturalized in many parts of the world, notably North America and Australia. The plant spreads rapidly by means of runners or from the prodigous seed production. In many parts of the United States it is considered a noxious weed. 